\title{
Why Do College Students Cheat? A Structural Equation Modeling Validation of the Theory of Planned Behavior
}

\author{
Saeed Abdullah AL-Dossary ${ }^{1}$ \\ ${ }^{1}$ Psychology Department, College of Education, Hail University, Saudi Arabia \\ Correspondence: Saeed Abdullah AL-Dossary, Psychology Department, College of Education, Hail University, \\ Saudi Arabia. E-mail: saeedaldossary@yahoo.co.uk
}

Received: February 17, 2017

doi:10.5539/ies.v10n8p40
Accepted: March 23, 2017 Online Published: July 29, 2017

URL: https://doi.org/10.5539/ies.v10n8p40

\begin{abstract}
Cheating on tests is a serious problem in education. The purpose of this study was to test the efficacy of a modified form of the theory of planned behavior (TPB) to predict cheating behavior among a sample of Saudi university students. This study also sought to test the influence of cheating in high school on cheating in college within the framework of the TPB. Analyses were conducted on a sample of 322 undergraduate students using structural equation modeling. The results were consistent with the TPB model's predictions. The TPB model explained a modest variance in cheating in college. When cheating in high school added to the model, the proportion of explained variance increased and cheating in high school was the best predictor of cheating in college. Although not hypothesized by the TPB, subjective norm had a direct effect on attitude.
\end{abstract}

Keywords: academic cheating, theory of planned behavior, structural equation modeling, Saudi Arabia

\section{Introduction}

Cheating on tests is a persistent problem in education and it is widespread among high school and college students (Davis, Grover, Becker, \& McGregor, 1992; MaCabe \& Trevino, 1993, 1997; Whitley, 1998; Williams \& Hosek, 2003). Much research has been conducted on student cheating behavior (e. g., Carpenter, Harding, Finelli, Montgomery, \& Passow, 2006; Jordan, 2001; Kisamore, Stone, \& Jawahar, 2007; McCabe, Butterfield, \& Trevino, 2006; McCabe, Trevino, \& Butterfield, 2001, 2002; Sideridis, Tsaousis, \& Al Harbi, 2016). Most of the research is descriptive. Focus has been on individual factors (e. g. age, gender, personality) or situational factors (e.g. honor codes, peer context, testing environment) to predict and explain cheating behavior. Currently, there is limited research into cheating behavior among Arabic students (Dodeen, 2012).

The theory of planned behavior (TPB) (Ajzen, 1991) is used to predict a variety of social behaviors. Several studies have investigated the efficacy of the TPB in predicting student cheating behavior (e. g., Beck \& Ajzen, 1991; Harding, Mayhew, Finelli, \& Carpenter, 2007; Passow, Mayhew, Finelli, Harding, \& Carpenter, 2006). Each of these studies found strong support for the TPB's explanation of student cheating behavior. However, no research to date has included all of the constructs in the model nor has their influence been estimated in a causal sequence. Only three studies (Mayhew, Hubbard, Finelli, Harding, \& Carpenter, 2009; Stone, Jawahar, \& Kisamore, 2009, 2010) provide a comprehensive and specific test of the model in causal sequence using structural equation modeling. However, these studies did not test the modified form of the TPB, with the exception of Mayhew, Hubbard, Finelli, Harding, and Carpenter (2009). While extensive research on cheating has been conducted on a western context, very little is known about the cheating behavior of Arab students specifically of Saudi students. Saudi Arabia is considered both conservative and collectivist society and great importance is placed on the needs, attitudes, and goals of the family rather than on the individual. Islam is the religion of Saudi Arabia and cheating is forbidden in Islam and against Islamic values. Thus, a major goal of the present study is to determine the explanatory power of the modified form of the TPB model in explaining cheating behavior of Saudi students using structural equation modeling. A second purpose of the study is to extend the model by considering an additional construct, high school cheating. It seeks to test the influence of cheating in high school on cheating in college within the framework of the TPB.

Cheating on tests is a serious problem in higher education because of its implications. Cheating violates institutional regulations and damages reputations. It negatively affects the accuracy of the evaluation by adding more sources of errors which decreases the validity of the measures of student learning. In addition, the 
ramifications of cheating extend beyond higher education. Research suggests that students who cheat in college are more likely to engage in unethical behavior in the workplace (Carpenter, Harding, Finelli, \& Passow, 2004; Grimes, 2004; Nonis \& Swift, 2001, Stone, Jawahar, \& Kisamore, 2016).

The TPB is designed to predict and explain human behavior in specific contexts. It has been applied extensively and successfully to predict numerous types of behavior such as smoking (Karimy, Zareban, Araban, \& Montazeri, 2015), breastfeeding (Guo, Wang, Liao, \& Huang, 2016), and physical activity (Wang \& Zhang, 2016). In a meta-analysis of 185 studies, Armitage and Conner (2001) found that the TPB explained 27\% and 39\% of the variance in behavior and intention, respectively.

The TPB postulates that individuals make rational decisions to engage in specific behaviors based on their personal beliefs about those behaviors and their expectations of a positive outcome by engaging in that behavior. According to the theory, intention to perform a behavior is the immediate predictor of behavior and it is determined by three factors: attitude toward a behavior, subjective norm, and perceived behavioral control. Attitude toward a behavior is an individual's positive or negative view of a particular behavior. Subjective norm refers to an individual's perception of whether people important to the individual feel that a particular behavior should be engaged in. Perceived behavioral control is an individual's perception of his or her ability to perform a particular behavior and is influenced by past experience and anticipated obstacles. Perceived behavioral control is expected to predict behavior when it is a reflection of actual behavioral control. Beck and Ajzen (1991) proposed a modified form of the TPB to include a measure of moral obligation described as "personal feelings of ...responsibility to perform, or to refuse to perform, a certain behavior” (Beck \& Ajzen, 1991, p. 289). Beck and Ajzen (1991) state that moral obligation is a needed factor when moral concerns are a primary factor of the behavior. Figure 1 depicts the modified form of the TPB model.

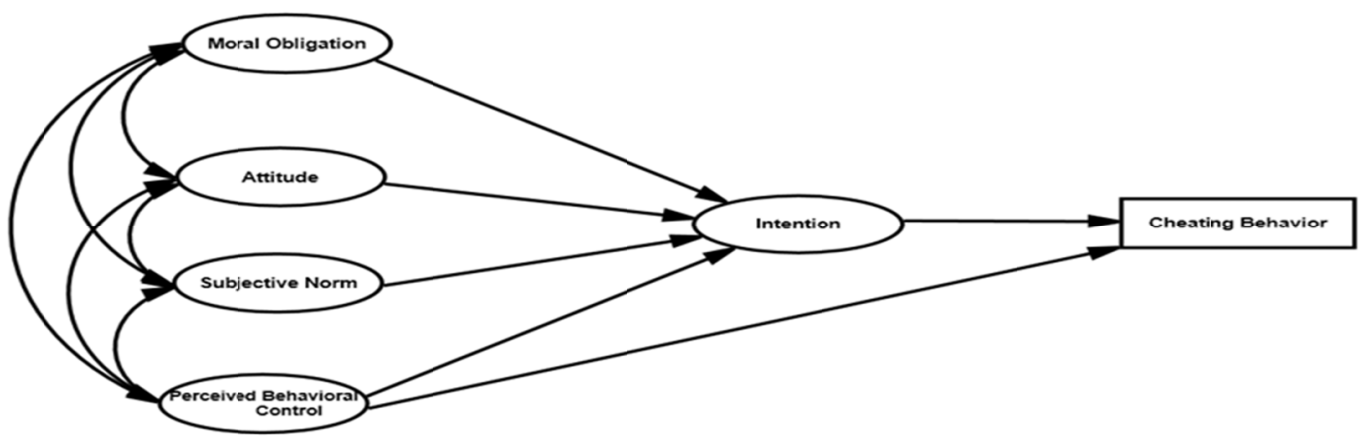

Figure 1. Path diagram for the modified form of TPB theoretical model

Although the TPB has been useful in predicting a wide variety of behaviors, its use in research on cheating is limited. In a meta-analysis of 16 studies, Whitley (1998) found that the TPB accounted for $27.8 \%$ of the variance in cheating behavior, with each component of the TPB model have a significant correlation with cheating behavior. Beck and Ajzen (1991) used the TPB to predict a range of dishonest actions, including cheating on tests. The TPB accounted for $67 \%$ of the variance in cheating intention and $55 \%$ of the variance in cheating behavior. However, subjective norms had no effect on intention and perceived behavioral control had no effect on behavior. In Stone et al.'s (2010) study on undergraduate cheating the TPB accounted for $21 \%$ and $36 \%$ of the variance in cheating intention and cheating behavior respectively. Harding et al. (2007) found general support for the TPB in predicting college cheating behavior, but perceived behavioral control was not a significant predictor of behavior. Mayhew et al. (2009) found that neither attitudes nor perceived behavioral control were significant predictors of intention or behavior when moral obligation was added to the TPB.

Despite the usefulness of the TPB in predicting cheating behavior, a large proportion of the variance in cheating behavior remains unexplained. This indicates that at least some important constructs may not be specified by the TPB. Researchers have tested the TPB with the addition of other constructs to improve the explanatory power of the model (Armitage \& Conner, 2001). Ajzen (1991) argues that the TPB is "open to the inclusion of additional predictors if it can be shown that they capture a significant proportion of the variance in intention or behavior after the theory's current variables have been taken into account" (p. 199). Cheating in high school has been found to predict cheating in college (Beck \& Azjen, 1991; Harding et al., 2007; Mayhew et al., 2009; Passow et 
al., 2006; Whitley, 1998). Students who report cheating in high school were more likely to report cheating in college. Therefore, this modified TPB will be tested with the added variable of cheating in high school. It is expected that the relationship between cheating in high school and intention to cheat will be mediated by attitude, subjective norm, and perceived behavioral control (Beck \& Ajzen, 1991). The hypothesized TPB model is shown in Figure 2.

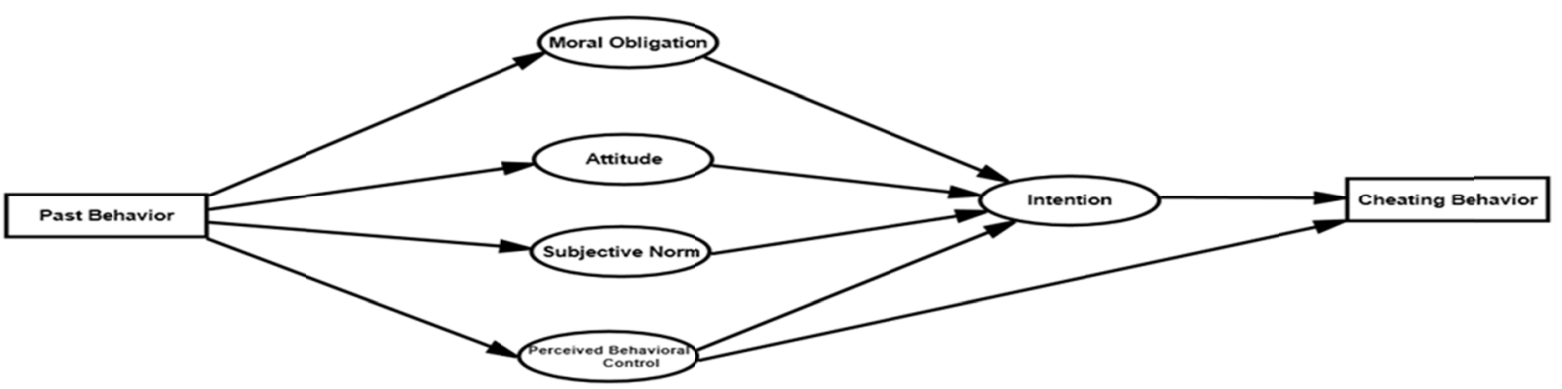

Figure 2. Path diagram for the modified model of TPB with the addition of high school cheating

The purpose of this study is to test the TPB model in a causal sequence using structural equation modeling for predicting college cheating behavior. A second purpose of the study is to test the influence of cheating in high school within the framework of the TPB.

\section{Method}

\subsection{Participants and Procedure}

Data were collected from a random sample of undergraduate students at Hail University in Saudi Arabia during the second semester of the academic year 2015-16. In order to obtain high response rates, students were asked to voluntarily complete a questionnaire in their classes. The questionnaire was administered by the researcher with help from faculty members. A total of 355 students participated in this study (68.7\% male and $31.3 \%$ female). They ranged in age from 18 to 29 years $(\mathrm{M}=22.09, \mathrm{SD}=1.83)$.

\subsection{Measures}

The variables were measured by 20 items adapted from Beck and Ajzen (1991). Behavioral and past behavioral were each measured by one item: "During the previous academic term in college, how frequently did you cheat on tests or exams?" and "During high school, how frequently did you cheat on tests or exam?" Responses ranged from 1 (never), 2 (a few of the times I took a test or exam), 3 (about half of the times I took a test or exam), 4 (almost every time I took a test or exam), to 5 (every time I took a test or exam). Attitude was measured by five items on a 5-point semantic differential scale: good-bad (A1), harmful-beneficial (A2), wise-foolish (A3), Pleasant- unpleasant (A4), Useful-useless (A5).

The remaining variables were assessed on a 5-point Likert scale ranging from 1 (strongly disagree) to 5 (strongly agree). Subjective norms were measured by three items: "If I cheated on a test or exam, most of the people who are important to me would not care" (SN1); "No one who is important to me thinks it is OK to cheat on a test or exam." (SN2); "Most people who are important to me will look down on me if I cheat on a test or exam." (SN3).

Four items were used to assess perceived behavioral control: "For me to cheat on a test or exam is easy." (PBC1); "If I want to, I can cheat on a test or exam." (PBC2); "I can imagine times when I might cheat on a test or exam even if I hadn't planned to." (PBC3); “Even if I had a good reason, I could not bring myself to cheat on a test or exam." (PBC4).

Behavioral intention was measured by three items: "If I had the opportunity, I would cheat on a test or exam."(INT1); "I would never cheat on a test or exam. "(INT2); and "I may cheat on a test or exam in the future" (INT3).

Moral obligation was measured by three items: "I would not feel guilty if I cheated on a test or exam." (MO1); "Cheating on a test or exam goes against my principles." (MO2); "It would be morally wrong for me to cheat on a test or exam." (MO3). 


\subsection{Data Analysis}

The data were analysed using Structural Equation Modelling (SEM) with Amos 18 software. SEM uses various types of models to depict relationships among variables. Various theoretical models can be tested in SEM to understand how sets of variables define factors and how these factors are related to each other (Schumacker \& Lomax, 2004).

Before running the SEM, the data were prepared for the analysis. The negatively worded items were reverse scored. In addition, the data were checked for missing values, outliers, and normality distributions according to the guidelines provided by Tabachnick and Fidell (2001) with SPSS 14 software.

As suggested by Jöreskog (1993) and Anderson and Gerbing (1988), a two-step structural equation modelling procedure was used in estimating parameters: a measurement model followed by a structural model. The measurement model, which is a confirmatory factor analysis, specified the relationships between variables and factors. It provided an assessment of reliability and validity of variables for each factor. The structural model specified the relationships among factors (Schumacker \& Lomax, 2004).

Several fit indices were used to assess the fit of the model as suggested by Byrne (1998). These indices were the Chi-square $\left(x^{2}\right)$ test, the Normed chi-square ( $x^{2} / d f$ ), Goodness-of-Fit index (GFI), Adjusted Goodness-of-Fit Index (AGFI), Comparative Fit Index (CFI), and Root Mean Square Error of Approximation (RMSEA). A non-significant chi-square value indicates that the model fits the data well. To determine the acceptable model fit of other indices, the cut-off values were: $x^{2} / \mathrm{df} \leqslant 3$, GFI, AGFI, CFI, $\geqslant .90$, and RMSEA $\leqslant .08$ (Browne \& Cudeck, 1993; Byrne, 2001; Hu \& Bentler, 1999).

\section{Results}

\subsection{Prevalence of Cheating on Tests during College and High School}

Percentages of male and female students admitting to cheating on tests during college and high school are shown in Table 1. Nearly half (46.5\%) of college students reported never cheating on tests. More than one quarter (29.3\%) reported cheating on tests few of the time. The remainder was students who reported cheating on tests about half of the time $(14.9 \%)$, almost every time $(4.5 \%)$, every time they had an opportunity $(2 \%)$, or did not report cheating behavior $(2.8 \%)$. There is also a significant gender difference $(\mathrm{p}<.05)$ in reporting never cheating on tests: $41 \%$ of males reporting never cheating on tests compared to $58.6 \%$ of females.

Similar patterns were seen in high school. Less than half (44.5\%) reported never cheating on tests, and more than one quarter $(25.9 \%)$ reported cheating on tests few of the time. The remaining $29.6 \%$ of students reported cheating on tests half of the time (10.4\%), almost every time (7\%), every time they had an opportunity $(6.5 \%)$, or did not report cheating behavior (5.6\%). In terms of gender differences, $49.5 \%$ of female students reported never cheating on tests compared to $42.2 \%$ of male students. This difference is not statistically significant.

\subsection{Data Screening}

In preparation of data for the analysis, data were screened for missing values, outliers, and normality distributions. There were some missing values. Missing values were evaluated with respect to both cases (Table 2) and variables (Table 3). 293 cases (82.54\%) had valid, non-missing values and 62 cases (17.46\%) had missing values. One variable had no missing values (SN1). The two variables with the highest proportion of missing values were cheating in college and cheating in high school with $5.6 \%$ and $2.81 \%$ of missing cases, respectively. Little's MCAR test was used to assess the pattern of missing values. If the p-value for Little's MCAR test is not significant, then the data can be assumed to be MCAR. Little's MCAR test showed that the missing values can be assumed to be MCAR $\left(\chi^{2}=529.95, \mathrm{df}=559, \mathrm{p}=0.806\right)$. There were 17 students did not report their cheating behaviour either during college or high school. Because cheating behaviour variables are important in this study, it was decided to delete them. In addition, it was decided to delete cases with more than $10 \%$ of missing values. The number of these cases was 11 . Therefore, the remaining data contained of 327 cases. 
Table 1. Percentages of male and female students who cheat

\begin{tabular}{|c|c|c|c|c|c|c|c|}
\hline & & Never & Few time & Half of the time & Almost & Every time & Did not report \\
\hline \multirow{3}{*}{$\begin{array}{c}\text { Cheating in } \\
\text { college }\end{array}$} & $\begin{array}{c}\text { Overall } \\
355\end{array}$ & $\begin{array}{c}165 \\
(46.5 \%)\end{array}$ & $104(29.3 \%)$ & $\begin{array}{c}53 \\
(14.9 \%)\end{array}$ & $\begin{array}{c}16 \\
(4.5 \%)\end{array}$ & $\begin{array}{c}7 \\
(2 \%)\end{array}$ & $\begin{array}{c}10 \\
(2.8 \%)\end{array}$ \\
\hline & $\begin{array}{c}\text { Males } \\
244 \\
\end{array}$ & $\begin{array}{c}100 \\
(41 \%) \\
\end{array}$ & $\begin{array}{c}79 \\
(32.4 \%)\end{array}$ & $\begin{array}{c}44 \\
(18 \%) \\
\end{array}$ & $\begin{array}{c}12 \\
(4.9 \%) \\
\end{array}$ & $\begin{array}{c}5 \\
(2 \%) \\
\end{array}$ & $\begin{array}{c}4 \\
(1.6) \\
\end{array}$ \\
\hline & $\begin{array}{c}\text { Females } \\
111 \\
\end{array}$ & $\begin{array}{c}65 \\
(58.6 \%) \\
\end{array}$ & $\begin{array}{c}25 \\
(22.5 \%) \\
\end{array}$ & $\begin{array}{c}9 \\
(8.1 \%) \\
\end{array}$ & $\begin{array}{c}4 \\
(3.6 \%) \\
\end{array}$ & $\begin{array}{c}2 \\
(1.8 \%) \\
\end{array}$ & $\begin{array}{c}6 \\
(5.4 \%) \\
\end{array}$ \\
\hline \multirow{3}{*}{$\begin{array}{l}\text { Cheating in } \\
\text { high school }\end{array}$} & $\begin{array}{c}\text { Overall } \\
355 \\
\end{array}$ & $\begin{array}{c}158 \\
(44.5 \%) \\
\end{array}$ & $\begin{array}{c}92 \\
(25.9 \%) \\
\end{array}$ & $\begin{array}{c}37 \\
(10.4 \%) \\
\end{array}$ & $\begin{array}{c}25 \\
(7 \%) \\
\end{array}$ & $\begin{array}{c}23 \\
(6.5 \%) \\
\end{array}$ & $\begin{array}{c}20 \\
(5.6 \%) \\
\end{array}$ \\
\hline & $\begin{array}{c}\text { Males } \\
244 \\
\end{array}$ & $\begin{array}{c}103 \\
(42.2 \%) \\
\end{array}$ & $\begin{array}{c}68 \\
(27.9 \%) \\
\end{array}$ & $\begin{array}{c}24 \\
(9.8 \%) \\
\end{array}$ & $\begin{array}{c}17 \\
(7 \%) \\
\end{array}$ & $\begin{array}{c}20 \\
(8.2 \%) \\
\end{array}$ & $\begin{array}{c}12 \\
(4.9 \%) \\
\end{array}$ \\
\hline & $\begin{array}{c}\text { Females } \\
111\end{array}$ & $\begin{array}{c}55 \\
(49.5 \%)\end{array}$ & $\begin{array}{c}24 \\
(21.6 \%)\end{array}$ & $\begin{array}{c}13 \\
(11.7 \%)\end{array}$ & $\begin{array}{c}8 \\
(7.2 \%)\end{array}$ & $\begin{array}{c}3 \\
(2.7 \%)\end{array}$ & $\begin{array}{c}8 \\
(7.2 \%)\end{array}$ \\
\hline
\end{tabular}

Table 2. The number of missing values by cases

\begin{tabular}{ccc}
\hline Number of cases & Number of missing in each cases & Percentages of missing in each cases \\
\hline $293(82.54 \%)$ & 0 & $0 \%$ \\
$42(11.83 \%)$ & 1 & $5 \%$ \\
$9(2.54 \%)$ & 2 & $10 \%$ \\
$7(1.97 \%)$ & 3 & $15 \%$ \\
$2(0.56 \%)$ & 4 & $20 \%$ \\
$2(0.56 \%)$ & 5 & $25 \%$ \\
\hline
\end{tabular}

Table 3. The number of missing values by variables

\begin{tabular}{lcc}
\hline Number of variables & Number of missing in each variable & Percentages of missing in each variable \\
\hline 1 (SN1) & 0 & $0 \%$ \\
$4(\mathrm{~A} 1, \mathrm{SN} 2, \mathrm{PBC} 2, \mathrm{MO} 3)$ & 1 & $0.28 \%$ \\
1 (PBC4) & 2 & $0.56 \%$ \\
2 (A2, MO1) & 3 & $0.84 \%$ \\
2 (PBC1, PBC3) & 4 & $1.12 \%$ \\
$3(\mathrm{~A} 3, \mathrm{MO} 2, \mathrm{I3})$ & 5 & $1.41 \%$ \\
$3(\mathrm{I} 1, \mathrm{SN} 3, \mathrm{~A} 4)$ & 6 & $1.69 \%$ \\
1 (I2) & 7 & $1.97 \%$ \\
1 (A5) & 9 & $2.53 \%$ \\
1 (PB) & 10 & $2.81 \%$ \\
1 (B) & 20 & $5.63 \%$ \\
\hline
\end{tabular}

Univariate and multivariate Outliers were detected. To assess univariate outliers, all variables were converted to z scores. Tabachnick and Fidell (2001) recommend considering cases with Z scores higher than $3.29(\mathrm{p}<.001$, two-tailed test) to be outliers. All cases were less than 3.28. Multivariate outliers were identified by computing each case's Mahalanobis distance and a case is considered as a multivariate outlier if the probability associated with its $\mathrm{D}^{2}$ is 0.001 or less (Tabachnick \& Fidell, 2001). Five multivariate outliers were identified and deleted. After deleting these cases, the remaining data contained of 322 cases.

Normalitiy distribution was assessed using skewness and kurtosis. Tabachnick and Fidell (2001) suggest that skewness and kurtosis values should be within the range of -2 to +2 when the variables are normally distributed. The values ranged between -.06 to 1.51 for skewness and between -1.32 and 1.75 for kurtosis. This indicated that the data is normality distributed.

SEM requires a large sample size. However, there is no agreement on how large a sample size is needed. Anderson and Gerbing (1988) consider sample sizes between 100 and 150 as the minimum for SEM. Kline (1998) recommends that sample sizes below 100 could be considered small, between 100 and 200 cases as medium size and samples that exceed 200 cases could be considered as large. However, models with more parameters require a larger sample. Mueller (1997) suggests that the ratio of the number of cases to the number 
of variables is recommended to be at least 10:1.

The sample size used in this study meets these recommendations. The sample size is 322 . In addition, as there were 50 free parameters and 18 variables in the hypothesis structural model, the ratio of the number of cases to the number of observed variables was 17.8:1. Therefore, the SEM could be conducted without a further problem.

\subsection{Measurement Models}

The measurement model is a confirmatory factor analysis (CFA). It provides an assessment of the reliability and validity of variables for each factor. The CFA was conducted on five factors and 18 items. The results indicated that two items (SN3 and PBC3) had very poor reliabilities as their squared factor loadings were less than 0.15 . Thus, the initial model was modified by deleting the two items. The results of the modified model are shown in Table 4. Although the chi-square of 201.147 with 94 degree of freedom was statistically significant at $\mathrm{p}<0.001$, all other fit indices were within acceptable values $\left(x^{2} / \mathrm{df}=2.139 ; \mathrm{GFI}=0.93\right.$; AGFI=0.90; CFI $=0.96$; RMSEA $=0.06$ ). All factors loadings were significant at $p<0.001$ and ranged from 0.62 to 0.95 , indicating that each item was well represented by the factors. Alpha coefficient reliabilities for all factors were well above the cut-point of .70 as suggested by Nunnaly and Bernstein (1994). Means, standard deviations and correlations between variables are provided in Table 5. All factors were significantly correlated with cheating behavior in college $(\mathrm{p}<0.001)$.

Table 4. Reliabilities and standardized confirmatory factor loadings for factors

\begin{tabular}{lc}
\hline Factor & All sample (322) \\
\hline Attitude & Cronbach's alpha $=0.91$ \\
A1 & 0.84 \\
A2 & 0.83 \\
A3 & 0.85 \\
A4 & 0.87 \\
A5 & 0.71 \\
Subjective norms & Cronbach's alpha $=0.73$ \\
SN1 & 0.85 \\
SN2 & 0.67 \\
Perceived behavioral control & Cronbach's alpha $=0.74$ \\
PBC1 & 0.76 \\
PBC2 & 0.72 \\
PBC4 & 0.62 \\
Behavioral intention & Cronbach's alpha $=0.86$ \\
INT1 & 0.88 \\
INT2 & 0.91 \\
INT3 & 0.70 \\
Moral obligation & Cronbach's alpha $=0.78$ \\
MO1 & 0.55 \\
MO2 & 0.75 \\
MO3 & 0.95 \\
\hline
\end{tabular}

Table 5. Means, standard deviations and correlations among variables

\begin{tabular}{lllllllll}
\hline & $\mathrm{M}$ & $\mathrm{SD}$ & 1 & 2 & 3 & 4 & 5 & 6 \\
\hline 1) Cheating behavior & 1.81 & 0.978 & & & & & & \\
2) Past Cheating & 1.98 & 1.216 & .52 & & & & & \\
3) Intention & 1.82 & 0.945 & .38 & .25 & & & & \\
4) Attitude & 2.11 & 0.978 & .54 & .41 & .49 & & & \\
5) Subjective norm & 1.77 & 0.873 & .27 & .25 & .40 & .52 & & \\
6) PBC & 2.28 & 0.979 & .33 & .25 & .39 & .37 & .32 & \\
7) Moral Obligation & 2.52 & 1.146 & .25 & .28 & .29 & .46 & .31 & .18 \\
\hline
\end{tabular}

Note. $\mathrm{PBC}=$ Perceived Behavioral Control, all correlations are significant at the .001 level. 


\subsection{Structural Models}

Structural equation modeling was employed to test two models. The first model was the modified form of the TPB (see Figure 1); while the second model added the variable cheating in high school within the framework of the modified form of the TPB (see Figure2). In the first model according to Beck and Ajzen (1991), attitudes, subjective norms, perceived behavioral control and moral obligation influence intention and both intention and perceived behavioral control in turn lead to behavior. The results of the theoretical structural model are shown in Figure 3. The results indicated that the chi-square of 295.465 with 109 degree of freedom was statistically significant at $\mathrm{p}<0.001$, indicating an inappropriate fit. However, it has been stated that the chi-square is highly sensitive to sample size and usually suggests a poor fit with large sample sizes (Byrne, 2001). Other fit indices were within the acceptable values except for GFI and AGFI, which were slightly lower than the commonly acceptable values of $0.90\left(\chi^{2} / \mathrm{df}=2.711\right.$; $\mathrm{GFI}=0.91$; $\mathrm{AGFI}=0.87$; $\mathrm{CFI}=0.93$; RMSEA $\left.=0.07\right)$. Overall, the results indicated a moderate fit between the data and the modified form of TPB model.

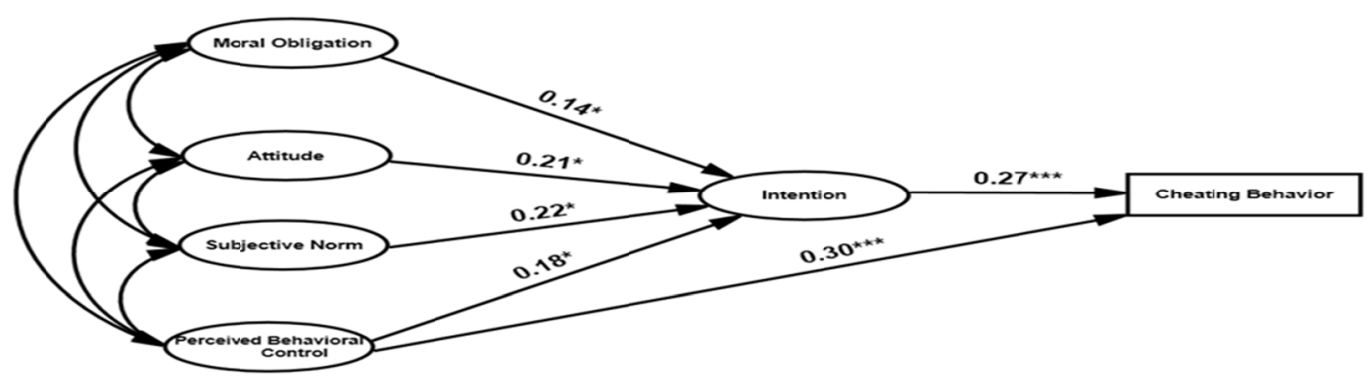

Figure 3. Path diagram for the modified form of TPB theoretical model, Notes: *** p-value $<0.001$; ** p-value $<0.01 ; *$ p-value $<0.05$

Attitudes $(B=0.21, p<0.05)$, subjective norm $(B=0.22, p<0.05)$, perceived behavioral control $(B=0.18, p<$ 0.05 ), and moral obligation $(\beta=0.14, p<0.05$ ) had direct effects on intentions, and collectively explained 30 percent of the variance in intention. Both perceived behavioral control $(B=0.30, p<0.001)$ and intention $(B=$ $0.27, \mathrm{p}<0.001)$ were found to have significant direct effects on cheating behavior and together explained 22 percent of the variance in cheating behavior.

The second model was to test the role of cheating in high school within the modified form of the TPB. It was hypothesized that components of the TPB mediated the influence of cheating in high school on intention to cheat and on behaviour. The results are reported in Figure 4. The model did not provide an acceptable fit to the data, $\left(x^{2} / \mathrm{df}=3.713 ; \mathrm{GFI}=0.86\right.$; AGFI=0.82; CFI 0.88 ; RMSEA $\left.=0.09\right)$. This model explained 27 percent of the variance in intention, and 22 percent of the variance in college cheating behavior. All paths were at least significant at $\mathrm{p}<0.05$.

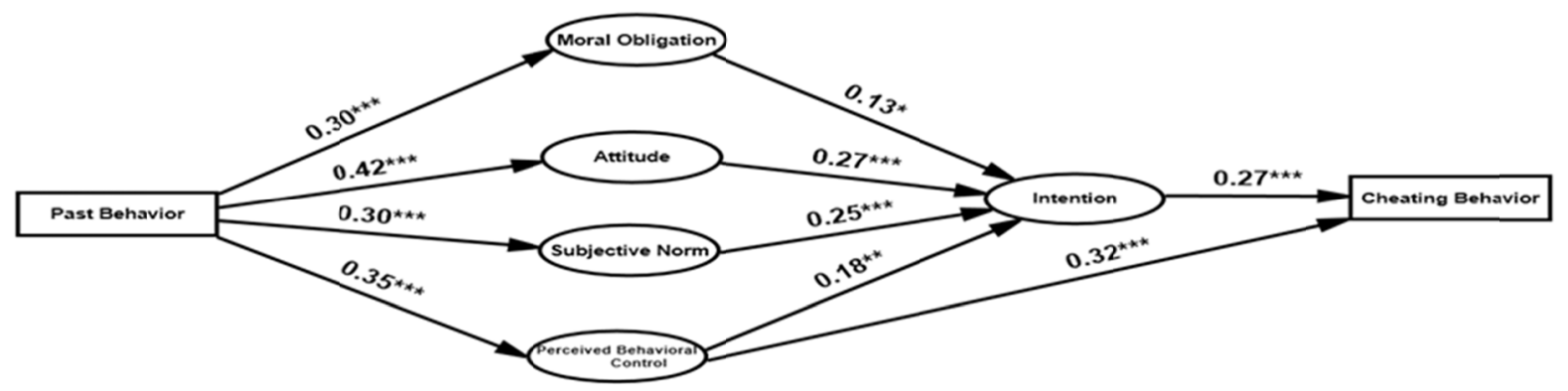

Figure 4. Path diagram for the initial modified model of TPB with the addition of high school cheating, Notes: *** p-value $<0.001 ; * *$ p-value $<0.01 ; *$ p-value $<0.05$ 
In order to achieve a better model fit the Modification Index (MI) suggested the model could be improved by adding several structural paths. However, it is important to note that structural equation modelling should be theory driven, and modifications should be made with theoretical grounding. Jöreskog and Sörbom (1993) suggest that a path with the large MI should be estimated and modification should be made in step. The largest MI (49.324) is represented by a path from subjective norm to attitudes. This implies that students' subjective norm had a direct effect on their attitudes. Chang (1998) also found a significant direct effect for subjective norm on attitudes for university students. Therefore, the first modified structural model was developed by adding one path from subjective norm to attitudes.

The results of the first modified structure model are shown in Figure 5. The results indicated that some fit indices were slightly lower than the commonly acceptable values $\left(x^{2} / \mathrm{df}=3.246\right.$; GFI $=0.88$; $\mathrm{AGFI}=0.83 ; \mathrm{CFI}=0.90$; RMSEA $=0.08$ ). In a review of the MI, it was found that the model could also have a better fit if a path form cheat in high school to cheat in college was added with MI of 42.249. This implies that students cheating in high school had a direct effect on their cheating behaviour in college. The effect of cheat in high school on cheating in college was consistent with prior results (Beck \& Azjen, 1991; Harding et al., 2007; Mayhew et al., 2009; Passow et al., 2006; Whitley, 1998). Therefore, the second modified structural model was developed by adding one path from cheat in high school to cheating in college.

The results of the second modified model are shown in Figure 6. All fit indices were within acceptable values except for AGFI which was slight lower than the commonly acceptable values of $0.90\left(\mathrm{x}^{2} / \mathrm{df}=2.752\right.$; GFI $=$ 0.90; AGFI $=0.88 ; \mathrm{CFI}=0.93$; RMSEA $=0.07$ ). This model accounted for more variance in intention and cheating behaviour than the previous models with $28 \%$ and $35 \%$, respectively. This model was considered to be the final model because the MI did not suggest adding any meaningful paths.

Cheating in high school had a direct influence on attitudes $(B=0.30, \mathrm{p}<0.001)$, moral obligation $(\beta=0.30, \mathrm{p}<$ $0.001)$, subjective norm $(\beta=0.29, p<0.001)$, and perceived behavioral control $(\beta=0.30, p<0.001)$. Subjective norm was found to have significant direct effect on attitudes $(\beta=0.47, p<0.001)$.

The largest direct effect on intention to cheat was exerted by subjective norm $(B=0.23, p<0.05)$, followed by attitudes $((\beta=0.22, p<0.05)$, perceived behavioral control $(\beta=0.20, p<0.01)$, and moral obligation $(\beta=0.15$, $\mathrm{p}<0.05)$. The largest direct effect on cheating behavior in college was exerted by cheating in high school $(\beta=$ $0.42, p<0.001)$, followed by intention to cheat $(\beta=0.21, p<0.001)$ and perceived behavioral control $(\beta=0.17$, $\mathrm{p}<0.01)$.

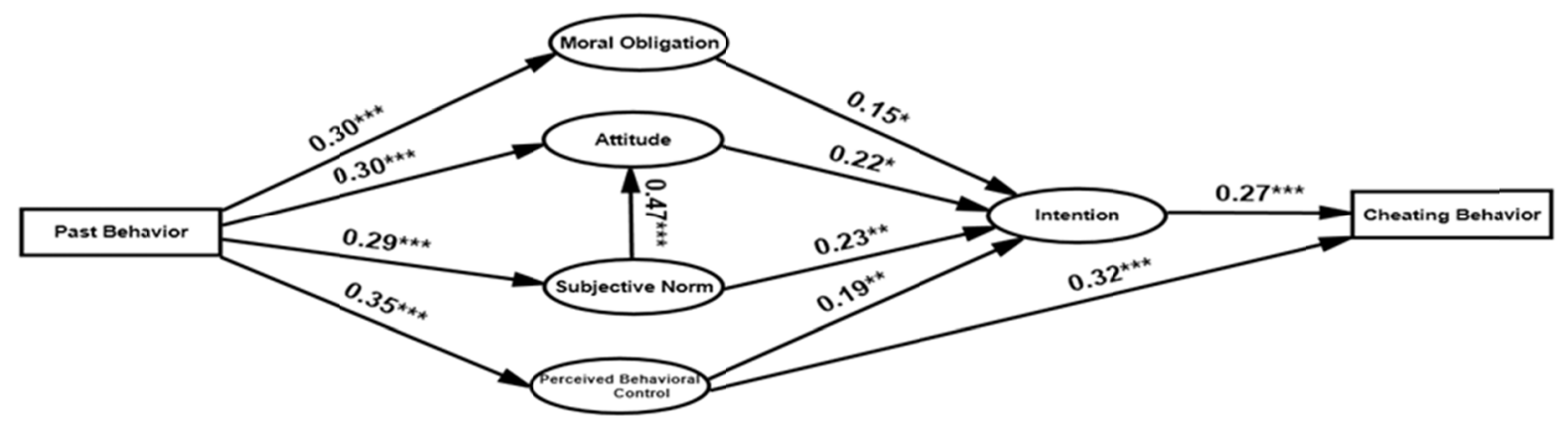

Figure 5. Path diagram for the first modified model of TPB with the addition of high school cheating, Notes: *** p-value $<0.001 ; * *$ p-value $<0.01 ; *$ p-value $<0.05$ 


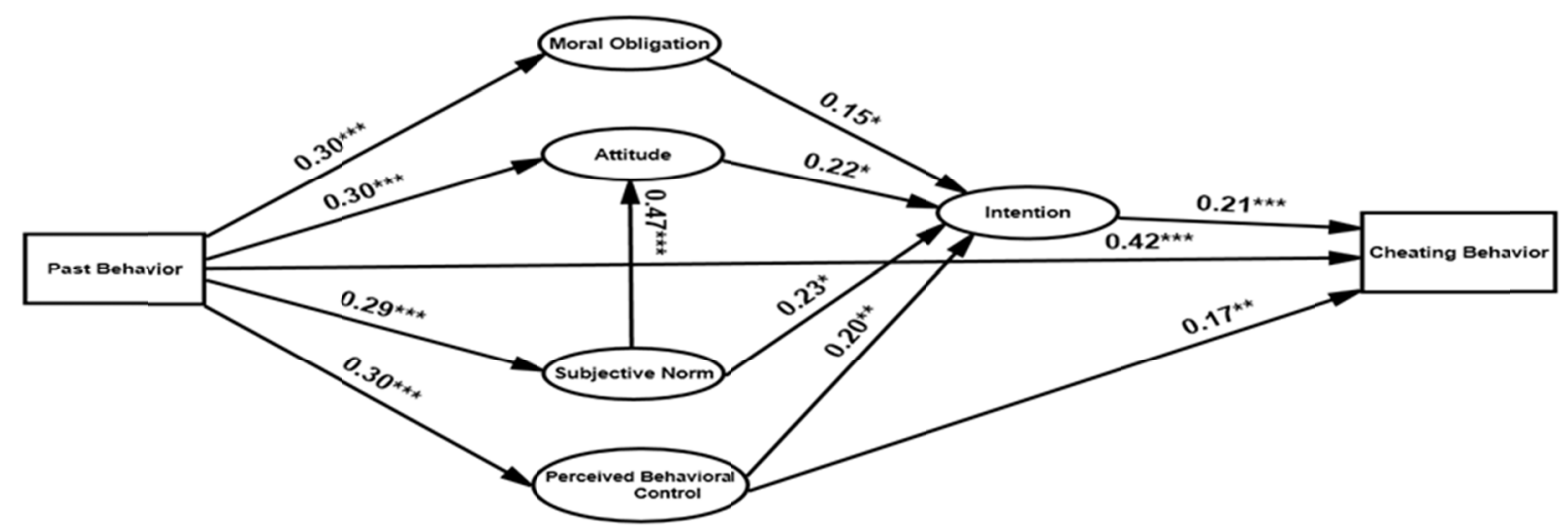

Figure 6. Path diagram for the second modified model of TPB with the addition of high school cheating, Notes: *** p-value $<0.001 ; * *$ p-value $<0.01 ; *$ p-value $<0.05$

The above results show only direct effects. The SEM also shows the indirect and the total effects. Table 6 reports the indirect, direct, and total effects of each factor on cheating behaviour in college, as well as the rank ordering of factors by magnitude of their total effects. As shown in Table 6, cheating in high school had the largest total effect on cheating in college. The second largest total effects on cheating in college were accounted for both students' intention to cheat and their perceived behavioural control.

Table 6. Indirect, direct, and total effects on college cheating behaviour

\begin{tabular}{lcccc}
\hline & Direct Effect & Indirect Effect & Total Effect & Ranking of Total Effects \\
\hline Moral Obligation & - & 0.03 & 0.03 & 5 \\
Attitudes & - & 0.05 & 0.05 & 4 \\
Subjective Norm & - & 0.07 & 0.07 & 3 \\
Perceived Behavioral Control & 0.17 & 0.04 & 0.21 & 2 \\
Cheat in High School & 0.42 & 0.11 & 0.53 & 1 \\
Intention & 0.21 & - & 0.21 & 2 \\
\hline
\end{tabular}

\section{Discussion}

This is the first study to use the TPB to explain cheating behavior in an Arabic context. The principle objective of this study was to determine the power of the modified form of the TPB in predicting student cheating behaviors using structural equation modeling. The results of the study provide support for the modified form of the TPB as attitude, subjective norms, perceived behavioral control and moral obligation predicted intention to cheat, and perceived behavioral control and intention were significant predictors of cheating behavior. The modified model of the TPB accounted for 30 percent of the variance in intention to engage in cheating and 22 percent of the variance in cheating behavior. Although modest, these percentages compare favorably with other studies (e. g. Harding et al., 2007; Stone et al., 2009, 2010; Whitley, 1998). Previous research has generally supported the predictive validity of the TPB in a western context. The present study suggests that the TPB is also reasonably useful in accounting for cheating behavior of individuals in an Arabic context.

The pattern of effects of the factors was consistent with the TPB. All of the TPB components were significant predictors of intention to engage in cheating. The largest effects were found to subjective norms followed by attitude. With regards to cheating behavior, both intentions to engage in cheating and perceived behavioral control had significant effects on cheating behavior.

Another objective of this study was to examine the influence of cheating in high school on cheating in college within the framework of the TPB. The addition of the variable cheating in high school enhanced the predictability of the TPB because the variance in cheating behavior increased from 22 percent to 35 percent. Students who cheated more often in high school were more likely to cheat on tests in college. Furthermore, cheating in high school had the largest total effect on cheating in college, a finding consistent with other research 
(Beck \& Azjen, 1991; Harding et al., 2007; Mayhew et al., 2009; Passow et al., 2006; Whitley, 1998). This underscores the power of high school behaviour in predicting college behaviour. Research has shown that certain behaviors during college can be predicted by a person's having engaged in them during high school, behaviors that students bring with them to college and that remain unchanged by the college experience (Astin, 1993, Pasceralla \& Terenzini, 2005, cited in Mayhew et al., 2009).

Another finding of this study was that subjective norm had a significant direct effect on attitude. This effect was not suggested by the TPB but is consistent with other research (Chang, 1998; Shepherd \& O'Keefe, 1984; Vallerand, Deshaies, Cuerrier, Pelletier, \& Mongeau, 1992). This implies that a student's attitude toward cheating is affected by what others think about it. According to the TPB, attitude towards a specific behavior is affected by beliefs about the positive and negative consequences of engaging in the behavior. If a student has positive beliefs towards cheating behavior, then the student will form a positive attitude toward cheating behavior. These beliefs are influenced by family, friends, and teachers.

This study has several implications for further research. First, few studies on cheating behavior have used structural equation modeling. It is recommended that future research use this method because it allows complex phenomena to be modeled and tested. Second, consistent with previous research, this study found that the TPB explained only a small proportion of the variance in student cheating behavior. This indicates that at least some important predictors of cheating behavior may not be properly identified by the theory. More research is needed to identify such predictors. The current study focused on factors drawn from the TPB with the addition of cheating in high school. Future research might investigate additional factors such as the role of religion. This might then increase the proportion of variance explained in any model of cheating behavior. Third, findings from previous studies and this current study indicate that a large number of students admitted to cheating and the future research could be directed to examine the efficacy of strategies to prevent cheating such as multiple grading opportunities, spaced seating and monitoring, multiple testing forms, and banning digital technologies. Finally, previous research and the current study found that men were more likely to cheat than women. This may indicate that the process leading to cheating behavior varies for men and women. Future research could examine the efficacy of the TPB across gender.

This study has limitations. It took place at one university; findings may not be generalizable to other populations. Also, the TPB variables were collected using self-report measures which are intrinsically vulnerable to social desirability bias. However, it is likely that this bias was minimal as the participants were assured complete anonymity and confidentiality. Additionally, there is evidence that self-report measures of cheating behavior can yield accurate information (Beck \& Ajzen, 1991; Becker, Connolly, Lentz, \& Morrision, 2006; Cizek, 1999). Finally, this study focused on cheating on tests. Future research could examine other types of cheating such as cheating on homework or plagiarism.

\section{References}

Ajzen, I. (1991). The theory of planned behavior. Organizational Behavior and Human Decision Processes, 50(2), 179-211. https://doi.org/10.1016/0749-5978(91)90020-T

Anderson, J. C., \& Gerbing, D. W. (1988). Structural equation modeling in practice: A review and recommended two-step approach. Psychological Bulletin, 103(3), 411-423. https://doi.org/10.1037/0033-2909.103.3.411

Armitage, C. J., \& Conner, M. (2001). Efficacy of the theory of planned behaviour: A meta-analytic review. British Journal of Social Psychology, 40(4), 471-499. https://doi.org/10.1348/014466601164939

Beck, L., \& Ajzen, I. (1991). Predicting dishonest actions using the theory of planned behavior. Journal of Research in Personality, 25(3), 285-301. https://doi.org/10.1016/0092-6566(91)90021-H

Becker, D., Connolly, J., Lentz, P., \& Morrison, J. (2006). Using the business fraud triangle to predict academic dishonestly among business students. Academy of Educational Leadership Journal, 10(1), 37-54.

Browne, M., \& Cudeck, R. (1993). Alternative ways of assessing model fit. In K. Bollen, \& J. Long (Eds.), Testing structural models (pp. 445-455). Newbury Park, CA: Sage.

Byrne, B. M. (1998). Structural equation modeling with LISREL, PRELIS and SIMPLIS: Basic concepts, applications and programming. Mahwah, NJ: Lawrence Erlbaum Associates.

Byrne, B. M. (2001). Structural equation modeling with AMOS: Basic concepts, applications, and programming. Mahwah, NJ: Lawrence Erlbaum Associates.

Carpenter, D. D., Harding, T. S., Finelli, C. J., \& Passow, H. J. (2004). Does academic dishonesty relate to unethical behavior in professional practice? An exploratory study. Science and Engineering Ethics, 10(2), 


\section{1-324. https://doi.org/10.1007/s11948-004-0027-3}

Carpenter, D. D., Harding, T. S., Finelli, C. J., Montgomery, S. M., \& Passow, H. J. (2006). Engineering students' perceptions of and attitudes towards cheating. Journal of Engineering Education, 95(3), 181-194. https://doi.org/10.1002/j.2168-9830.2006.tb00891.x

Chang, M. K. (1998). Predicting unethical behavior: A comparison of the theory of reasoned action and the theory of planned behavior. Journal of Business Ethics, 17, 1825-1834. https://doi.org/10.1023/A:1005721401993

Cizek, G. J. (1999). Cheating on tests: How to do it, detect it, and prevent it. Mahwah, NJ: Lawrence Erlbaum Associates.

Davis, S. F., Grover, C. A., Becker, A. H., \& McGregor, L. N. (1992). Academic dishonesty: Prevalence, determinants, techniques, and punishments. Teaching of Psychology, 19(1), 16-20. https://doi.org/10.1207/s15328023top1901_3

Dodeen, H. M. (2012). Undergraduate student cheating in exams. Damascus University Journal, 28(1), 37-55.

Grimes, P. W. (2004). Dishonesty in academics and business: A cross-cultural evaluation of student attitudes. Journal of Business Ethics, 49(3), 273-290. https://doi.org/10.1023/B:BUSI.0000017969.29461.30

Guo, J. L., Wang, T. F., Liao, J. Y., \& Huang, C. M. (2016). Efficacy of the theory of planned behavior in predicting breastfeeding: Meta-analysis and structural equation modeling. Applied Nursing Research, 29, 37-42. https://doi.org/10.1016/j.apnr.2015.03.016

Harding, T. S., Mayhew, M. J., Finelli, C. J., \& Carpenter, D. D. (2007). The theory of planned behavior as a model of academic dishonesty in engineering and humanities undergraduates. Ethics \& Behavior, 17(3), 255-279. https://doi.org/10.1080/10508420701519239

Hu, L., \& Bentler, P. M. (1999). Cutoff criteria for fit indexes in covariance structure analysis: Conventional criteria versus new alternatives. Structural Equation Modeling: A Multidisciplinary Journal, 6(1), 1-55. https://doi.org/10.1080/10705519909540118

Jordan, A. E. (2001). College student cheating: the role of motivation, perceived norms, attitudes, and knowledge of institutional policy. Ethics \& Behavior, 11(3), 233-247. https://doi.org/10.1207/S15327019EB1103_3

Jöreskog, K. G. (1993). Testing structural equation models. In K. A. Bollen, \& J. S. Long (Eds.), Testing structural models (pp.294-316). Newbury Park, NJ: Sage.

Jöreskog, K., \& Sörbom, D. (1993). LISREL 8: Structural equation modeling with the SIMPLIS command language. Chicago: Scientific Software, Inc.

Karimy, M., Zareban, I., Araban, M., \& Montazeri, A. (2015). An extended theory of planned behavior (TPB) used to predict smoking behavior among a sample of Iranian medical students. International Journal High Risk Behaviors \& Addiction, 4(3), 1-7. https://doi.org/10.5812/ijhrba.24715

Kisamore, J. L., Stone, T. H., \& Jawaher, I. M. (2007). Academic integrity: The relationship between individual and situational factors on misconduct contemplations. Journal of Business Ethics, 75(4), 381-394. https://doi.org/10.1007/s10551-006-9260-9

Kline, R. (1998). Principles and practice of structural equation modeling. New York: Guildford Press.

Mayhew, M. J., Hubbard, S. M., Finelli, C. J., Harding, T. S., \& Carpenter, D. D. (2009). Using structural equation modeling to validate the theory of planned behavior as a model for predicting student cheating. The Review of Higher Education, 32(4), 441-468. https://doi.org/10.1353/rhe.0.0080

McCabe, D. L., \& Trevino, L. K. (1993). Academic dishonesty: Honor codes: honor codes and other contextual influences. The Journal of Higher Education, 64(5), 522-538. https://doi.org/10.2307/2959991

McCabe, D. L., \& Trevino, L. K. (1997). Individual and contextual influences on academic dishonesty: A multicampus investigation. Research in Higher Education, 38(3), 379-396. https://doi.org/10.1023/A:1024954224675

McCabe, D. L., Butterfield, K. D., \& Trevino, L. K. (2006). Academic dishonesty in graduate business programs: Prevalence, causes and proposed action. Academy of Management Learning \& Education, 5(3), 294-305. https://doi.org/10.5465/AMLE.2006.22697018

McCabe, D. L., Trevino, L. K., \& Butterfield, K. D. (2001). Dishonesty in academic environments: The influence of peer reporting requirements. The Journal of Higher Education, 72(1), 29-45. 
https://doi.org/10.2307/2649132

McCabe, D. L., Trevino, L. K., \& Butterfield, K. D. (2002). Honor codes and other contextual influences on academic integrity: A replication and extension of modified honor code settings. Research in Higher Education, 43(3), 357-378. https://doi.org/10.1023/A:1014893102151

Mueller, R. O. (1997). Structural equation modeling: Back to basics. Structural Equation Modeling: A Multidisciplinary Journal, 4(4), 353-369. https://doi.org/10.1080/10705519709540081

Nonis, S., \& Swift, C. O. (2001). An examination of the relationship between academic dishonesty and workplace dishonesty: A multicampus investigation. Journal of Education for Business, 77(2), 69-77. https://doi.org/10.1080/08832320109599052

Nunnally, J. C., \& Bernstein, I. H. (1994). Psychometric theory (3rd ed.). New York: McGraw-Hill.

Passow, H. J., Mayhew, M. J., Finelli, C. J., Harding, T. S., \& Carpenter, D. D. (2006). Factors influencing engineering students' decisions to cheat by type of assessment. Research in Higher Education, 47(6), 643-684. https://doi.org/10.1007/s11162-006-9010-y

Schumacker, R. E. \& Lomax, R. G. (2004). A beginner's guide to structural equation model (2nd ed.). Mahwah, NJ: Lawrence Erlbaum Associates.

Shepherd, G. J. \& O'Keefe, D. J. (1984). Separability of attitudinal and normative influences on behavioral intentions in the Fishbein-Azjen model. The Journal of Social Psychology, 122, 287-288. https://doi.org/10.1080/00224545.1984.9713496

Sideridis, G. D., Tsaousis, I., \& Al Harbi, K. (2016). Predicting academic dishonesty on national examinations: The role of gender, previous performance, examination center change, city change, and region change. Ethics \& Behavior, 26(3), 215-237. https://doi.org/10.1080/10508422.2015.1009630

Stone, T. H., Jawahar, I. M., \& Kisamore, J. L. (2010). Predicting academic misconduct intentions and behavior using the theory of planned behavior and personality. Basic and Applied Social Psychology, 32(1), 35-45. https://doi.org/10.1080/01973530903539895

Stone, T. H., Jawahar, I. M., \& Kisamore, J. L. (2016). Predicting workplace misconduct using personality and academic behaviors. In R. J. Burke, E. C. Tomlinson, \& C. L. Cooper (Eds.), Crime and corruption in organizations (pp.97-119). New York, NY: Routledge.

Stone, T., H., Jawahar, I. M., \& Kisamore, J. L. (2009). Using the theory of planned behavior and cheating justifications to predict academic misconduct. Career Development International, 14(3), 221-241. https://doi.org/10.1108/13620430910966415

Tabachnick, B., \& Fidell, L. (2001). Using multivariate statistics (4th ed.). Boston, MA: Allyn and Bacon.

Vallerand, R. J., Deshaies, P., Cuerrier, J., Pelletier, L. G., \& Mongeau, C. (1992). Azjen and Fishbein's theory of reasoned action as applied to moral behavior: A confirmatory analysis. Journal of Personality and Social Psychology, 62, 98-109. https://doi.org/10.1037/0022-3514.62.1.98

Wang, L., \& Zhang, Y. (2016). An extended version of the theory of planned behaviour: The role of self-efficacy and past behaviour in predicting the physical activity of Chinese adolescents. Journal of Sports Sciences, 34(7), 587-597. https://doi.org/10.1080/02640414.2015.1064149

Whitley, B. E. (1998). Factors associated with cheating among college students: A review. Research in Higher Education, 39(3), 235-274. https://doi.org/10.1023/A:1018724900565

Williams, M. S., \& Hosek, W. R. (2003). Strategies for reducing academic dishonesty. Journal of legal Studies Education, 21(1), 87-107. https://doi.org/10.1111/j.1744-1722.2003.tb00326.x

\section{Copyrights}

Copyright for this article is retained by the author(s), with first publication rights granted to the journal.

This is an open-access article distributed under the terms and conditions of the Creative Commons Attribution license (http://creativecommons.org/licenses/by/4.0/). 